\title{
ASSOCIATED VIRUSES THREATENING SWEETPOTATO IMPROVEMENT AND PRODUCTION IN ETHIOPIA
}

\author{
A. ADANE \\ Ethiopia Agricultural Research Institute. P. O. Box 2003, Addis Ababa, Ethiopia \\ Corresponding author: adaneabraham@yahoo.com
}

\begin{abstract}
The level of virus contamination on sweetpotato germplasm resources in Ethiopia was determined. Sweetpotato (Ipomea batatus) accessions in fields at Awassa and Wondo Genet Research Stations had 85\% typical virus symptoms with up to 100\% incidence. The associated viruses were identified by Enzyme-linked immunosorbent assay (ELISA). Accordingly, out of 57 accessions serologically tested from Awassa, 22 and 21 were found to be infected by Sweetpotato feathery mottle virus (SPFMV) and Sweetpotato chlorotic stunt virus (SPCSV). Only one was infected by Sweetpotato virus 2 (SPV2). Similar serological analysis of 122 accessions from Wondo Genet revealed that SPFMV is the most frequent (64.7) followed by SPCSV (10.7\%) and SPV2 in only two accessions. This is the first report of the occurrence of SPCSV and SPV2 in Ethiopia. There was a high virus contamination level of sweetpotato germplasm resources in Ethiopia.
\end{abstract}

Key Words: Enzyme-linked immunosorbent assay, germplasm, Ipomea batatus

\section{RÉSUMÉ}

Le niveau de contamination virale sur les ressources de germoplasme de la patate douce en Ethiope a été déterminé. Les accessions de patate douce (Ipomea batatus) aux champs des stations de recherche d' Awassa et dans les stations de recherche de Wondo Genet a avaient (85\%) de symptômes de virus typic avec environ 100 \% d'incidence. Les virus associés étaient indentifés par l'Enzyme d'analyse immunosorbant (ELISA). En conséquence, parmi les 57 accessions d'Awassa sérologiquement testées, 22 et 21 étaient trouvées infectées par la Sweetpotato feathery mottle virus (SPFMV) et Sweetpotato chlorotic stunt virus (SPCSV), alors que le sweet potato virus 2 (SPV2) n’avait affecté qu'une seule. ). Une analyse serological similaire de 122 nouvelles accessions de Wondo Genet avaient révélé que SPFMV est le plus fréquent $(64,7)$ suivi de SPCSV $(10,7 \%)$ et SPV2 dans seulement deux accessions. Ceci est le prmier rapport sur l'occurrence de SPCSV et SPV2 en Ethiopie. Il y avait eu un niveau très élevé de contamination virale du germoplasme de patate douce en Ethiopie.

Mots Clés: Enzyme-associé d'essai immunosorbant, germoplasme, Ipomea batatus

\section{INTRODUCTION}

Transmission via plant propagation materials including vegetative part like tuber, bulbs, budwood or cutting is one of the important strategies for spread and survival of many plant viruses. It is of considerable significance in the ecology of these viruses. Propagule-transmitted viruses are of particular importance in crop germplasm resources for three main reasons
(Hampton et al., 1982). Firstly, if infected germplasm is used in breeding programmes, viruses will inevitably increase in the process of variety multiplication, and thus later be disseminated when the seed or vegetative planting material is distributed to growers resulting in economic loss. Secondly, such contaminated germplasm may act as a vehicle for introducing viruses to geographical areas where the viruses do not occur. Thirdly, it would 
be difficult for the breeder to properly characterise virus-infected germplasm as the resulting plants will be of lesser vigour and yield. Thus, testing of crop germplasm resources and subsequent cleaning to obtain virus-free accessions offers strategic opportunity to disease control.

Crops propagated vegetatively are known to be particularly prone to contamination by viruses (Spiegel et al., 1993). Thus, research and development efforts to test and clean up propagule-borne viruses from germplasm resources have concentrated on these groups of crops. A large collection of crop germplasm resources is present in the national agricultural research institutions in Ethiopia for use in crop improvement programmes. Experience in other countries shows that a number propagule-borne viruses exist, some of which can be of serious agricultural importance and contaminate some of these germplasm resources (Spiegel et al., 1993).

Reports available on the virus infection in Ethiopia indicated that many soybean (Abraham and Albrechtsen, 1998)and lentil and few pea germplasm resources (Abraham and Makkouk, 2002) are contaminated by viruses. Except for these few studies, no further information is available on virus occurrence and level of contamination on germplasm resources particularly of the vegetatively propagated crops in the country. In recent years, however, researchers at the national agricultural research systems are concerned about the unusually high infection rates of what is suspected to be a virus disease in sweetpotato accessions used by the improvement programme. It was, therefore, important to determine the identity of the causal viruses and the level of contamination of sweetpotato germplasm resources as a first step to minimise further dissemination of the viruses.

\section{MATERIALS AND METHOD}

Sweetpotato for virus symptoms and sample collection. Field inspections were made in the experimental sweetpotato fields at Awassa in November, 2006 and Wondo Genet in May, 2007, Agricultural Research Stations where germplasm resources and improved varieties are being maintained for national use. Plots of pre- national and national variety trials, maintenance plots of germplasm resources and released varieties were assessed for virus-like symptoms. Accessions from each plot were individually evaluated for the presence of virus-like symptoms and from each genotype, 3-10 vines with leaves that were with or without viral symptoms were collected for virus identification. Symptom evaluation, sample collection and laboratory analyses were done for 57 accessions from Awassa and 122 from Wondo Genet research stations. Cuttings of ten symptomatic sweetpotato accessions were planted in pots in a greenhouse to confirm the reproduction of symptoms and further scoring. In addition, some sweetpotato fields near the research stations owned by farmers were randomly inspected.

Serological analysis. Serological tests were carried out at the laboratory of Ambo Plant Protection Research Centre, Ethiopian Institute of Agricultural Research, to determine the identity of the virus(es) associated with both symptomatic and asymptomatic sweetpotato plants using antibodies for six viruses or strains known to infect the crop in Africa. A composite leaf sample of 3-10 symptomatic or asymptomatic plants collected from each accession was mixed, homogenised and used as a sample for serological test. Standard versions of Enzyme-linked immunosorbent assay (ELISA) were used to identify the association of one or more of six viruses known to infect sweetpotato worldwide in each sample. Polyclonal antibodies and the corresponding conjugates for Sweetpotato latent virus (SPLV, genus Potyvirus, family Potyviridae), Sweetpotato virus G (SPVG, genus Potyvirus, family Potyviridae) and Sweetpotato virus 2 (SPV2, genus Potyvirus, family Potyviridae) were used in double antibody sandwich (DAS) ELISA (Clark and Adams, 1977). On the other hand, triple antibody sandwich (TAS)-ELISA was used for identification of Sweetpotato feathery mottle virus (SPFMV, genus Potyvirus, family Potyviridae), Sweetpotato chlorotic stunt virus (SPCSV, genus Crinivirus, family Clostroviridae) and Sweetpotato mild mottle virus (genus Ipomovirus, family Potyviridae) 
using specific monoclonal antibodies as described by Abraham et al. (2006). For SPCSV, monoclonal antibodies specific to east African (Kenyan) and West African (Gabon) strains were used in separate assays. All the antibodies and conjugates were kindly supplied by Dr. H.J. Vetten, of Julius Kuehn Institute, Braunschweig, Germany.

\section{RESULTS}

Sweetpotato virus disease symptoms and field incidence. Most of the sweetpotato accessions observed in Awassa and Wondo Genet fields had typical virus-like symptoms (Tables 1 and 2). Similar symptoms were reproduced in plants developed from infected cuttings in the greenhouse. The symptoms included stunting, yellowing, mottling, leaf distortion and deformation. The number of sweetpotato genotypes evaluated, the presence of symptoms in each genotype and the identity of viruses identified are summarised in Table 1. In accessions with symptomatic plants, the incidence ranged from trace in some to $100 \%$ as in accessions like CN-2053.2 and 440229 at Awassa. Some of the highly infected entries had poor establishment, that is, suspected to be due to virus infection. These symptoms resemble those described for sweetpotato virus disease (SPVD) described in Africa or elsewhere. A less extensive inspection of some farmers' sweetpotato fields also indicated the occurrence of virus symptoms ranging from trace to $80 \%$ incidence.
Viruses identified on sweetpotato accessions and their incidence. Three viruses namely sweetpotato featherly mottle virus (SPFMV), sweetpotato chlorotic stunt virus (SPCSV) and sweetpotato virus (SPV2) were identified from germplasm resources at both locations. At Awassa, SPFMV and SPCSV, the two most important viruses of the crop worldwide, were nearly equally prevalent being found on 22 and 21 genotypes respectively, while SPV2 was found only in one genotype out of 57 accessions (Table 1). Seven accessions had mixed infection of SPFMV and SPCSV. At Wondo Genet, SPFMV was the most prevalent detected in 79 out of 127 tested (62\%) followed by SPCSV which was found at relatively lower proportion $(13 / 127,10 \%)$ as compared to that at Awassa. The SPV2 was detected in two accessions (1.6\%). On some accessions with clear viruslike symptoms, no virus was detected whereas some plants with no observable symptom were found to be infected with one or more virus (Table 1). The list of accessions infected by individual viruses or mixed infection at Awassa and Wondo Genet are presented in Tables 2 and 3. All samples were negative for SPMMV, SPLV and SPVG at both locations. Another interesting finding is that SPCSV, West African strain was found in two accessions at Awassa.

\section{DISCUSSION}

We for the first time report the occurrence of SPCSV, the most devastating sweetpotato virus worldwide, and SPV2 in research stations in

TABLE 1. Proportion of sweetpotato accessions on which virus-like symptoms and/or individual viruses are detected by ELISA

\begin{tabular}{lccc}
\hline Symptoms/viruses & \multicolumn{2}{c}{ Detected (\%) } & Total \\
\cline { 2 - 3 } & Awassa & Wondo Genet & \\
\hline Symptomatic & 68.4 & 93.4 & 85.5 \\
SPFMV & 38.6 & 62.2 & 56.5 \\
SPCSV & 36.8 & 10.2 & 18.5 \\
SPFMV+SPCSV & 12.3 & 3.9 & 6.5 \\
SPV2 & 1.8 & 1.6 & 0.6 \\
\hline
\end{tabular}

N = 57 and 122 for Awassa and Wondo Genet, respectively 
TABLE 2. Viruses detected on 57 sweetpotato accessions at Awassa as detected by ELISA

\begin{tabular}{|c|c|c|c|c|c|c|c|c|c|}
\hline \multirow[t]{2}{*}{ Accessions } & \multirow[t]{2}{*}{ Symptom } & \multicolumn{3}{|c|}{ Viruses identified } & \multirow[t]{2}{*}{ Accessions } & \multirow[t]{2}{*}{ Symptom } & \multicolumn{3}{|c|}{ Viruses identified } \\
\hline & & SPFMV & SPCSV & SPV2 & & & SPFMV & SPCSV & SPV2 \\
\hline Belela & + & - & + & - & CN-1753.1B & + & - & - & - \\
\hline Ordolo & + & - & & - & CN-17523 & + & + & + & - \\
\hline TIS 82/0602.6 & + & + & $+(G)$ & - & CN-2353.2 & + & + & - & - \\
\hline 440164 & - & - & + & - & TIS-9068.7 & + & + & $+(G)$ & - \\
\hline CN-1752.5 & + & + & - & - & Tainuing No.15 & + & + & + & - \\
\hline 440226 & + & + & + & - & 19900511 & + & + & + & - \\
\hline TIS 9068.7 & + & + & + & - & Damota & + & - & - & - \\
\hline Mugande & - & - & - & - & Bareda & + & + & - & - \\
\hline 18800.1 & - & + & - & - & 440392 & - & - & - & - \\
\hline 440016 & + & - & _ & + & TIS-8250-7 & - & - & - & - \\
\hline TIS-84411.4 & + & + & + & - & Temesgen & + & - & - & - \\
\hline Hudade & - & - & + & - & CN-2053.2 & $+(100 \%)$ & + & + & - \\
\hline 4402186 & + & - & + & - & TIS 968-7 & & + & - & - \\
\hline CN-1752.6 & + & + & + & - & Comental & + & - & - & - \\
\hline Koka-12 & + & & + & - & Kero & + & - & - & - \\
\hline CN-175.5 & + & - & - & - & Lugambe & - & - & - & - \\
\hline Maria Angola & - & - & - & - & 440027 & - & - & - & - \\
\hline SataAmaro & + & + & + & - & Kemb.39 & - & + & + & - \\
\hline Dubo & + & - & - & - & Koka 6 & + & - & - & - \\
\hline TIS-9068.5 & - & - & - & - & CN-265.15 & - & - & - & - \\
\hline 440024 & + & - & - & - & Beletech & + & - & + & - \\
\hline CN-173.24 & + & - & - & - & 440228 & $+(100 \%)$ & - & - & - \\
\hline CN-2065-11 & + & + & + & - & CN-206868 & + & - & - & - \\
\hline Felaha & - & - & - & - & CN-2060.4 & - & + & - & - \\
\hline Awassa 83 & + & - & - & - & Tula & + & + & + & - \\
\hline 19906.1 & - & + & + & - & CN-1754.2 & + & - & - & - \\
\hline BPI-SP2 & + & - & - & - & CN-2065-12 & - & - & - & - \\
\hline CN-2054.6 & + & - & - & - & CN-A53-1A & - & - & - & - \\
\hline Kulfo & + & + & - & - & & & & & \\
\hline
\end{tabular}

+ = typical symptom present or positive by ELISA, - = no symptom or negative by ELISA to the respective virus Virus Acronyms: SPFMV = Sweet potato feathery mottle virus, SPCSV = Sweet potato chlorotic stunt virus, SPV2 = Sweet potato virus 2. (G) implies reaction with antibody to SPCSV isolate from Gabon, (West Africa)

Ethiopia. Owing to the continuous exchange of planting materials with the research system and farmers and vector transmission of these viruses, it is anticipated that the viruses already occur in farmers' fields at least in the areas near the research stations. Indeed, a limited visual inspection of these fields in this work and a more extensive survey of viruses in sweetpotato farmers fields in southern Ethiopia done recently (Tewodros et al., unpublished data) indicate a high prevalence, incidence and increased economic importance.

Viruses have previously never been major limiting factors in sweetpotato production in
Ethiopia. The first report of a virus on sweetpotato in the country was made over two decades ago by electron microscopy of sweetpotato plants with mosaic symptoms from Nazreth, the virus being tentatively identified as SPFMV (SPL, 1986). Recently, however, Tameru (2004) reported a high incidence of SPFMV in some fields and the occurrence of another virus named as SPVG mainly from Wolayta zone.

It is reported that for sweetpotato cultivars, SPFMV alone does not show clear symptoms and remains a latent infection that manifests in combined infections with SPCSV (Karyeija et al., 
Viruses threatening sweetpotato production

TABLE 3. Viruses detected on 122 sweetpotato accessions at Wondo Genet tested by ELISA

\begin{tabular}{|c|c|c|c|c|c|c|c|c|c|}
\hline \multirow[t]{2}{*}{ Accessions } & \multirow[t]{2}{*}{ Symptom } & \multicolumn{3}{|c|}{ Viruses identified } & \multirow[t]{2}{*}{ Accessions } & \multirow[t]{2}{*}{ Symptom } & \multicolumn{3}{|c|}{ Viruses identified } \\
\hline & & SPFMV & SPCSV & SPV2 & & & SPFMV & SPCSV & SPV2 \\
\hline Guntutie & + & + & - & + & TIS-1487(20) & + & - & - & - \\
\hline CN-1517 & + & - & - & - & Gura-chera & + & + & - & - \\
\hline Costanero & + & + & - & - & 192054 -VII & - & - & + & - \\
\hline TIS-192054-IV & + & - & - & - & CN-2065 - II & + & + & & + \\
\hline TIS-2534 & + & + & - & - & TIS8250-8 & + & - & - & - \\
\hline TIB (11) (02) & + & + & - & - & 192054-TX & + & - & - & - \\
\hline Candee 440140 & + & - & - & - & CN-2059- 1 & - & + & - & - \\
\hline TIS-8250 & + & - & - & - & Becule-type-1 & + & + & - & - \\
\hline TIS 2009V & + & + & - & - & TIS8441-6 & + & & - & - \\
\hline Yanshu & + & + & - & - & Wadada & + & + & - & - \\
\hline TIS-38/ 0138 & + & + & - & - & APID & + & + & - & - \\
\hline Narunmitang & + & + & & - & 19240-VI & + & + & & - \\
\hline TIB-4 & + & + & + & - & 420009 & + & + & & - \\
\hline 440443 & + & - & - & - & Koka- 10 & + & + & & - \\
\hline TIS-5125(112) & + & - & - & - & Becuie type-3 & + & + & & - \\
\hline Mugande & + & + & - & - & 384 & + & - & + & - \\
\hline Jewel (440031) & + & & - & - & CN-1754 -9 & + & - & - & - \\
\hline Unknown-2 & + & + & - & - & TIS-8210602-3 & + & - & - & - \\
\hline Jewel & + & + & - & - & 365 & + & - & - & - \\
\hline Tainuning 64 & + & + & + & - & CN-1754-8 & + & + & - & - \\
\hline SPK-004 & - & + & + & - & CN- $2054-$-II & + & & - & - \\
\hline Kemb-10 & + & + & + & - & CN-2054 -3 & + & + & - & - \\
\hline TIS5125(112) & + & + & - & - & Koka- 26 & + & + & + & - \\
\hline Centenial & + & + & - & - & Becule & + & & - & - \\
\hline Cemsa & + & + & - & - & TIS-82 /0602-12 & + & & - & - \\
\hline $199062-1$ & + & + & - & - & TIS-9464-9-b & + & + & - & - \\
\hline TIS-902040-1 & + & + & - & - & TIS-9464-9-c & + & & - & - \\
\hline Mugamb & + & + & - & - & CN-1753-1b & + & + & - & - \\
\hline W-154 & + & + & - & - & Wolayta-Í & + & + & - & - \\
\hline 199005-11 & + & & - & - & Bareda & + & - & - & - \\
\hline L323 & + & & - & - & TIS-82(8602-1) & + & - & - & - \\
\hline Jonatan 430014 & + & + & & - & TIS-8250-4 & - & - & - & - \\
\hline Nemanti & + & + & + & - & $188005-1$ & + & + & - & - \\
\hline Tainuing No65 & - & - & - & - & Abadiro & + & + & - & - \\
\hline 396 & + & - & - & - & Koka-6 & + & + & - & - \\
\hline $8441-2$ & + & - & - & - & 368 & + & & - & - \\
\hline CN-1754-5 & - & - & - & - & 380 & + & + & - & - \\
\hline CN-1219-I & + & - & - & - & CN-1752-16 & + & + & - & - \\
\hline TIS-84-41-4 & + & - & - & - & TIS-4465-6 & + & + & - & - \\
\hline 192054-VIII & + & + & + & - & CN-1032(16) & + & - & - & - \\
\hline 402 & + & + & + & - & TIS 8441-3 & + & - & - & - \\
\hline 400004 & + & - & - & - & TIS 8250-7 & - & + & - & - \\
\hline 385 & + & + & - & - & TIS-9068-7 & + & - & - & - \\
\hline I92040 & + & - & - & - & 377 & + & - & - & - \\
\hline Duboo & + & - & - & - & TIS-9465-2 & + & + & - & - \\
\hline CN-1752-7 & + & + & - & - & CN2065-8 & + & + & & - \\
\hline 364 & + & + & - & - & Wendogenet & + & + & + & - \\
\hline Alemaya -I & + & + & - & - & 373 & + & + & - & - \\
\hline 396 & + & - & - & - & Caba & + & + & - & - \\
\hline |-192001 & + & + & - & - & TIS-70357-5 & + & - & - & - \\
\hline 192009- VIII & + & + & - & - & CN-1753-14 & + & + & - & - \\
\hline Koka- 3 & + & + & - & - & Baracuty & + & + & - & - \\
\hline TIB-1-110-2 & + & + & - & - & TIS-192026-Í & - & - & - & - \\
\hline CN-2065-10 & + & + & - & - & 440392 & + & + & & - \\
\hline CN-1032(16) & + & + & + & - & CN-2065-6 & + & + & & - \\
\hline TIS-82 / 0602-2 & + & + & - & - & Ajae-222 & + & + & + & - \\
\hline $19200-\|$ & + & + & - & - & TIS-80673 & + & + & - & - \\
\hline $192008-$ III & + & + & - & - & AIS-35-2 & + & + & - & - \\
\hline CN-1753-2A & + & + & - & - & Becule(Goradema) & + & + & - & - \\
\hline CN-2059-7 & + & - & - & - & 440377 & + & + & - & - \\
\hline CN-1752-11 & + & - & - & - & 440089 & + & - & - & - \\
\hline
\end{tabular}

$+=$ typical symptom present or positive by ELISA, $-=$ no symptom or negative by ELISA to the respective virus. Virus Acronyms: SPFMV $=$ Sweet potato feathery mottle virus, SPCSV = Sweet potato chlorotic stunt virus, SPV2 = Sweet potato virus 2. (G) implies reaction with antibody to SPCSV isolate from Gabon, (West Africa). All samples were negative for Sweet potato mild mottle virus, Sweet potato virus $G$ and Sweet potato latent virus 
2000). The SPCSV on the other hand, can cause severe symptoms alone or commonly in combination with SPFMV. Sweetpotato virus disease (SPVD), a major production constraint of the crop in Africa, is commonly attributed to the synergistic interaction of the SPFMV and SPCSV in mixed infection (Karyeija et al., 2000).

In a previous survey, SPCSV was not encountered and, hence, SPVD was suggested as absent in Ethiopia (Tameru, 2004). The results here establish the occurrence of both viral components of SPVD for the first time. Nevertheless, the detection of SPFMV but not SPCSV with many symptomatic accessions calls for further investigations as to whether SPFMV can alone cause severe sweetpotato disease in Ethiopian germplasm resources or that the SPCSV exists in the plants but not at concentration level detectable by ELISA. It is also not clear whether the lack of reports on SPCSV in Ethiopia is due to a more recent introduction of SPCSV or smaller number of samples (cuttings) obtained from research stations in the previous work. Since, a strong synergistic association distinct from SPCSV and SPV2 (synonym: SPVY) has also been reported in some sweetpotato cultivars (Souto et al., 2003), the occurrence of the three viruses known to be economically important alone or by forming synergistic interaction to one another calls for urgent and coordinated efforts to stop their further spread via germplasm resources to the farming community.

There can be different reasons for the failure to detect viruses particularly SPCSV in some accession with clear virus-like symptoms. It is reported that viruses are erratically distributed in infected sweetpotato and are present in very low concentration that they could not be reliably detected and that there is a need to collect tissues from different parts of a plant for ELISA (Green et al., 1988). Failure to detect sweetpotato virus infection by ELISA and even molecular methods like RT-PCR has also been observed frequently (Souto et al., 2003). Serological test of samples after graft inoculation to universal indicator plants such as Ipomea setosa as suggested by Green (1988) may be used to minimise such kind of escape in future works. The other possible reason is that there are new viruses or strains that could not be identified with the set of antibodies employed in this study.

Some plants with no observable symptom are found infected with one or more virus (Table 1 and 2) suggesting latent infection. It is possible that these clones are tolerant to the viruses and, thus, tested positive. These accessions after further confirmation may be introduced into the production system as tolerant cultivars. It should also be noted that even some non-infected accessions can be contaminated by viruses in the field as the viruses can readily be transmitted by aphids or whitefly vectors from infected to healthy accessions.

It is not quite clear why SPCSV is more prevalent in germplasm resources at Awassa than Wondo Genet, while SPFMV is equally prevalent in both locations. One possible explanation was that the generally warmer condition at Awassa were more favourable for the whitefly vector of SPCSV than Wondo Genet, thus facilitating within field spread of the virus.

The other viruses, namely, SPMMV, SPLV and SPVG were not detected and, thus, may be absent or occur rarely in the country. Surveys done in other east African countries like Uganda (Mukasa et al., 2003) and Kenya (Ateka et al., 2003) also indicated that these viruses were rare in farmers' fields. Tameru (2004), however, reported the occurrence of SPVG in farmers' field in some clones. The finding that these three viruses are not encountered at both Awassa and Wondo Genet research stations suggests that they either do not occur or are of minor importance in sweetpotato germplasm in Ethiopia.

In conclusion, it is shown that viruses including those previously unknown to the country contaminate the Ethiopian sweetpotato germplasm resources at high level. Urgent measures to stop their further spread across the production systems along improved materials throughout the country is needed, particularly in the cropping system in southern Ethiopia where sweetpotato plays a great role as a food security crop. 


\section{ACKNOWLEDGEMENT}

Thanks to Ato Engida Tsegaye from Awassa Agricultural Research Centre for help during collection of samples of sweetpotato accessions from trial plots at Awassa and Wondo Genet. Dr. H.J. Vetten, Julius Kuehn Institute, Braunschweig, Germany kindly provided all the antibodies and conjugates used in this study.

\section{REFERENCES}

Abraham, A. and Albrechtsen, S.E. 1998. Seedborne viruses infecting some important crops in Ethiopia. Pest Management Journalof Ethiopia 2:94-101.

Abraham, A. and Makkouk, K.M. 2002. The incidence and distribution of seedtransmitted viruses in pea and lentil seed lots in Ethiopia. Seed Science and Technology 30:567-574.

Abraham, A.D., Menzel, W., Lesemann, D.-E., Varrelmann, M. and Vetten, H. J. 2006. Chickpea chlorotic stunt virus: a new polerovirus infecting cool-season food legumes in Ethiopia. Phytopathology 96: 437-446.

Ateka, M.E., Njeru, R.W., Kibaru, A.G, Kimenju, K.W., Barg, E., Gibson, R.W. and Vetten, H.J. 2004. Identification and distribution of viruses infecting sweetpotato in Kenya. Annals of Applied Biology 144:371-379.

Clark, M.F. and Adams, A.N. 1977. Characteristic of the microplate method of enzyme-linked immunoassay for the detection of plant viruses: Journal of Genetics and Virology 34:475-83.

Green, S.K. 1988. Importance of viruses and mycoplasma-like organisms in the International transfer of sweetpotato germplasm. p.189-208. In: Viruses of Plants in
Africa. Williams, A.O., Mbiele, A.L. and Nkouka, (Eds.). CTA, Lagos, Nigeria.

Green, S.K., Kuo, Y.G. and Lee, D.R. 1988. Uneven distribution of two potyviruses (feathery mottle virus and sweetpotato latent virus) in sweetpotato plants and their implication on virus-indexing of meristem derived plants. Tropical Pest Management 34:298-302

Hampton, R.O. Waerworth, H., Goodman, R.M. and Lee, R. 1982. Importance of seed-borne viruses in crop germplasm. Plant Disease 66:977-78

Karyeija, R. F., Kreuze, J. F., Gibson, R. W., and Valkonen, J.P. T. 2000. Synergistic interactions of a potyvirus and a phloem limited crinivirus in sweetpotato plants. Virology 269:26-36

Mukasa S. B., Rubaihayo P. R., and Valkonen J.P.T. 2003. Incidence of Viruses and VirusLike Diseases of Sweetpotato in Uganda. Plant Disease 87:329-335

Spiegel, S, Frison, E.A. and Converse, R.H. 1993. Recent developments in therapy and virus detection procedures for the international movement of clonal plant germplasm. Plant Disease 77:1176-1180.

SPL (Scientific Phytop atological Laboratory). 1986. Progress report for the period 1985/ 86, pp. 252-259, Ambo, Ethiopia.

Souto, E.R., Sim, J. Chen, J., Valverde, R.A. and Clark, C.A. 2003. Properties and strains of Sweetpotato feathery mottle virus and two newly recognized potyviruses infecting sweetpotato in the United States. Plant Disease 87:1226-1332

Tameru Alemu. 2004. Characterization of viruses of pepper (Capsicum spp.) and sweetpotato (Ipomea batatas) from Ethiopia. Doctoral Dissertation. University of Bonn. 126 pp. 